\title{
1. Introduction: constitutionalism and religion in an age of consolidation and turmoil
}

\author{
Susanna Mancini
}

\section{SECULARIZATION, MODERNIZATION AND THE LEGACY OF THE ENLIGHTENMENT PROJECT}

Reflecting upon the inspiration behind her masterpiece, Memoirs of Hadrian, novelist Marguerite Yourcenar pointed to a sentence she had come across in 1973, in a volume of Gustave Flaubert's correspondence: "Just when the gods had ceased to be, and the Christ had not yet come, there was a unique moment in history, between Cicero and Marcus Aurelius, when man stood alone." ${ }^{1}$ While Flaubert's assertion might be historically questionable, ${ }^{2}$ it undoubtedly captures the extraordinary "mental and spiritual world" of pre-Christian Roman intellectual circles, ${ }^{3}$ whose life was free of religious constraints and filled with moral options - none of which reinforced by a divine force, all of which opened to rational discussion. For two decades, Yourcenar worked on her novel, "trying to define, and then trying to portray, that man existing alone and yet closely bound with all beings." 4 Indeed, her portrait of Hadrian, the Emperor of Rome from 117 to $138 \mathrm{AD}$, is the emblem of an unconstrained mind in search of the truth. Hadrian lucidly sees the inner contradictions and the limitations of all philosophical and religious doctrines. His initial curiosity for Christianity soon turns into the awareness that it will inevitably lead to sectarianism. At the end of his life, Hadrian no longer believes in the possibility of universal knowledge; he has become skeptical and disenchanted.

Ever since the Enlightenment, social thinkers have foreseen modernization as conducing to something close to Hadrian's condition, or Flaubert's mythical Roman "world without religion." Throughout the nineteenth and twentieth centuries, the most prominent philosophers, sociologists and anthropologists all concurred that modernization inevitably entailed the twilight of religion. Karl Marx considered religion as an epiphenomenon - a pathological product of a wrong world, bound to disappear once all injustices would be redressed. ${ }^{5}$ Liberal theorists pointed to the fundamental incompatibility between the rational character of Western modernity and the irrational force of religion. In Max Weber's influential sociology of religion, modernity emerged in the West through a process of rationalization, which unraveled the

\footnotetext{
1 Marguerite Yourcenar, Memoirs of Hadrian: And, Reflections on the Composition of Memoirs of Hadrian 319-20 (1963).

2 Between Cicero (106-43 BCE) and Marcus Aurelius (121-180 CE), many Romans were still polytheist: see A Companion to Roman Religion (Jörg Rüpke ed., 2007). Moreover, Christianity was on the rise under Marcus Aurelius, who carried on several persecutions against Christians: see Paul Keresztes, Marcus Aurelius a Persecutor?, 61 The Harvard Theological Review 321-41 (1968).

Stephen Greenblatt, The Swerve: How the World Became Modern 71 (2012).

YOURCENAR supra note 1 , at 320.

5 Nikolaus Lobkowicz, Karl Marx's Attitude Toward Religion, 26 The Review of Politics 319-52 (1964).
} 
conflation of ethical, religious and legal norms that was typical of pre-modern law, followed by a process of disenchantment. The intersection of these two processes led to the replacement of the superstitious and ceremonial law of primitive peoples by the integration of faith and reason of Christianity and the other monotheistic religions; and later, by entirely reason-based modern secular norms issued from the Enlightenment. ${ }^{6}$

The ideals of the Enlightenment presuppose a secular constitutional frame. ${ }^{7}$ Thus, while the place of religion in the public sphere and its relationship with the state have been crucial since Constantine - and particularly since the advent of the protestant Reformation - from a constitutional standpoint, secularism emerged as a necessary corollary of the ideal of the Enlightenment: the separation of faith from reason and equal liberty for all. According to the conventional narrative of the Enlightenment, the impossibility of fully capturing religion within the limits of reason made it necessary to decouple the realms of politics, scientific research and education from the bounds of religion. In addition, any endorsement of one denomination to the exclusion or marginalization of others would be in principle unacceptable, as it would inevitably undermine adherence to the principle of equal liberty for all. The expulsion of religion from the public sphere, where members of different faith-based communities must interact on an equal footing, is thus necessary to institutionally guarantee the dual aims of the Enlightenment. Separation of faith from reason is fostered by entrusting the public sphere to the latter and by allowing full expression of the former within the private sphere. Equal liberty is sustained, on the other hand, by the principle of neutrality between religious denominations in the public sphere and by securing the same freedom for all religions within the private sphere. Constitutional secularism may be construed variously as requiring outright expulsion of religion from the public sphere, as customarily understood in the context of French laïcité, or as merely called upon to insure that the state remain equidistant as between all religions within the polity. In either case, what remains imperative for constitutional secularism is that religion be depoliticized. ${ }^{8}$ The Enlightenment project thus confined religion to the private sphere.

This conventional narrative has notoriously been countered by many social theorists. In the first place, the presumed neat dichotomy between private and public has proven unsustainable. As feminist theory has abundantly made clear, the private sphere - which is constructed by the Enlightenment as that of family relations, sexuality and reproduction - is inherently political. Modern citizenship is structurally gendered citizenship: women's relegation in the family and their deprivation of political rights are the payoffs for men's political equality and freedom in the public sphere. Sexual difference is thus political difference and the private sphere is charged with political significance. ${ }^{9}$ Accordingly, the confinement of religion within the private sphere had two consequences: first, it exempted religion from democratic control; and second, it made space for religious norms to regulate gender and family relations, sexuality and reproduction.

6 Max Weber, Economy and Society: An Outline of Interpretive Sociology. Vol. 2644 ff. (1922) [1978].

See Michel Rosenfeld's chapter in this volume.

8 Susanna Mancini and Michel Rosenfeld, Introduction, in Constitutional Secularism IN AN AgE of Religious Revival xv et seq. (Susanna Mancini and Michel Rosenfeld eds., 2014).

9 Carol Pateman, The Sexual Contract (1988). 
Furthermore, the privatization of religion did not result in any neat expulsion of religious influence on political thinking. Indeed, privatization resulted in secularization and universalization of religion, and thus in its penetration and amalgamation into liberal political theory. This becomes manifest if one remembers that the Western concept of secularism is inescapably tied to the Christian religious tradition. Moreover, historically, secularism is the process of separation of the state from Christian churches, not from religion as such. It thus entails not only an obvious accommodation of Christian majorities, but also the culturalization of Christianity and its infusion into the entire fabric of the polity. The Enlightenment did not expel religion from the public sphere, but rather transformed it. Thus, "[f]rom being a concrete set of practical rules attached to specific processes of power and knowledge, religion has come to be abstracted and universalized."10 The above equation of secularized Christianity with universally valid values made room for the deployment of the secular state ideal in the West. Western models of managing the relationship between religion and the state vary considerably. France and the United States are traditionally described as strictly secular; whereas the United Kingdom, the Scandinavian countries and Greece provide models where an official religion coexists with institutionalized tolerance for minority religions. Italy and Spain constitute a middle-ground model, where special privileges are conferred upon the majority Catholic Church within an otherwise secular frame. From a constitutional standpoint, however, all Western models of managing religion are steeped in the normative order issuing from the Enlightenment. Hence, irrespective of their differences, they all adhere to two fundamental principles: the separation of church and state in the public sphere; and the protection of freedom of and from religion within the private sphere. Many constitutions reflect this dual constitutional prescription. Thus, the U.S. Constitution's "Establishment Clause" prohibits the state from adopting, preferring or endorsing a religion; whereas its "Free Exercise Clause" enjoins the state from interfering with the religious freedom of its citizens. Article 1 of the French Constitution specifies the secular character of the Republic and the duty of the state to respect all beliefs. Other constitutions only contain a freedom of religion clause, but implicitly embed separation in the founding principles of the system.

In other areas of the world, the transplant of the Western project of modernity set in motion different dynamics. In the first place, Western modernity - being built on the premise of liberal individualism - has been rightly accused of not paying sufficient attention to the idea of community. ${ }^{11}$ Accordingly, the Western conception of religious freedom as an individual right to be asserted against the state and society does not adequately capture - and has the potential to undermine - the communal dimension of religion that predominates in many different religious cultures. Most importantly, Western modernity developed in a context infused by the absolutist culture of Christianity. The fractures among Christian denominations did not prevent the common identification of Europeans with the Christendom, ${ }^{12}$ starting as early as 732, with the victory of Charles Martel over the Islamic forces. But other areas of the world did not follow a similar path. The case of Eastern Asia, which has traditionally been characterized by religious pluralism, comes to mind. As Peter Berger explains:

\footnotetext{
10 Talal Asad, Genealogies of Religion 42 (1992).

11 Partha Chatterjee, Community in the East, 33 Economic and Political Weekly 277-82 (February 7-13, 1998).

12 Peter Hulme, Colonial Encounters 84 (1986).
} 


\section{Constitutions and religion}

all over the region, different worldviews, religious traditions and even schools of moral thought have existed side by side quite amicably, and individuals have often utilized different traditions, simultaneously or at different stages of life, in a manner that seems illogical or irreverent to a Western observer. $^{13}$

The idea of relativity was thus traditionally embedded in a context suffused with a plurality of religious traditions and ethics - Buddhism, Shintoism, Confucianism and Christianity - and did not constitute a traumatic break from the past. Indeed, while "the pre-modern pluralism of Chinese, Japanese and Korean cultures could [...] be seen as a facilitation factor in the process of modernization," ${ }^{14}$ Christian theology resisted and resented modernity, for dethroning it and forcing it to live as "one among many"15 competing religious and secular conceptions. As the case of East Asia shows, the path that led to Western modernity has not been universally validated. As Charles Taylor warns, "the belief that modernity comes from one single universally applicable operation imposes a falsely uniform pattern on the multiple encounters of non-Western cultures." 16 In particular, the assumption that modernity necessarily emerges out of the fading of religious and metaphysical beliefs erroneously implies that there is a necessary convergence among the paths of different civilizations. ${ }^{17}$ One should acknowledge the existence of multiple modernities, that do not necessarily proceed through secularization, and separation between the state, society and religion.

The structural tensions within Western secularism, and the diversity that characterizes the relationship between state and religion across non-Western societies, did not prevent the world from experiencing a long period of, so to say, religious peace. Western, and particularly European, societies became increasingly secular and Christian churches made their peace with the secular state. After the Second World War, constitutionalism provided a frame for protecting religious minorities. ${ }^{18}$ By the middle of the twentieth century, freedom of religion was also recognized as a fundamental human right, in all international human rights treaties. Beyond the Iron Curtain, Communist regimes repressed religious expression, structurally eliminating the potential for conflicts between state and religion. A similar dynamic was at play in other contexts, such as Iran and Egypt, ruled by secular authoritarian leaders.

Toward the end of the 1970s, this equilibrium began to unravel.

13 Peter L. Berger, Secularity: West and East, in Cultural Identity and Modernization in Asian Countries (Kokugakuin Daigaku and Nihon Bunka Kenkyūjo eds., 1983, www2.kokugakuin.ac.jp/ijcc/ $\mathrm{wp} / \mathrm{cimac} /$ index.html, last accessed January 3, 2020).

14 Id.

15 Gustavo Zagrebelsky, One Among Many? The Catholic Church Between Universalism and Pluralism, in Mancini and Rosenfeld (eds.), supra note 8, at 247-68.

16 Charles Taylor, Two Theories of Modernity, 25 The Hastings Centre Report 24-25 (1995).

17 Id.

18 Dieter Grimm, Conflicts Between General Laws and Religious Norms, in Mancini and Rosenfeld (eds.), supra note 8 , at 3. 


\section{THE RE-POLITICIZATION OF RELIGION: A THREAT TO PUBLIC REASON}

The sociologist José Casanova has famously remarked that since the Iranian Revolution of 1979, the world has witnessed the resurgence of strong religions - that is, of religions that re-claim a space as protagonists in the public sphere and, specifically, in the political arena. ${ }^{19}$ The resurgence of strong religion must be placed in the broader context of the historical processes of secularization, globalization, mass migration and democratization.

The optimism that characterized the post-Second World War period was replaced by uprooting and unsettling expectations, exacerbated by the inexorable march of neoliberal economy. Accordingly, religion regained a commanding urgency as a response to disenchantment with the world, as a source of purpose, stability and empowerment.

It should thus not come as a surprise that while religiosity has progressively decreased in specific areas of the world - such as China, Japan, Western Europe, Canada and Oceania - the rest of the globe has experienced the opposite trend..$^{20}$ Today, the majority of the world population is religious; and in many regions of the globe, religiosity is on the rise among younger generations. It is thus to be expected that, globally, the number of people who consider themselves religious will continue to increase. ${ }^{21}$ Around the world, state-centered identities and politics have weakened with the erosion of the Cold War, making room for regroupings of religious, as well as ideological and political, collective actors. "Communal religious movements have developed within Hindu and Buddhist cultures, generally sharing strong antimodern and/ or anti-Western themes." 22 Other significant examples include the rise and spread of fundamentalist movements within Muslim, Jewish, and Protestant Christian communities. Many modernizing societies have rejected the homogenizing path of the Western model of secular modernity, and have relied on religious tradition to distance themselves from the colonial past and pursue autonomous projects of social transformations. ${ }^{23}$ In other words, the country's majority religious tradition is no longer perceived as an obstacle to the country's road to modernization; but it is used to challenge the notion that modernity is possible exclusively in European forms, and to assert the possibility of alternative forms of modernity that build on the country's traditional religious culture. Often, the rejection of the previous generation's secular aspirations and the reappropriation of the indigenous religion go hand in hand with a heavily conservative or fundamentalist interpretation of the latter. In post-colonial countries, religions and religious institutions play key roles in democratic transitions, state building ${ }^{24}$ and state policies. Islamists have become political protagonists in countries previously ruled by secular autocratic leaders, as exemplified by the role of the Muslim Brotherhood in the election of Egyptian President Mohamed Morsi in 2012.

\footnotetext{
19 José Casanova, Public Religions in the Modern World (1994).

20 See the 2015 survey of 65 countries, conducted by Gallup International and the WI Network of Market Research: www.washingtonpost.com/blogs/worldviews/files/2015/04/WIN.GALLUP -INTERNATIONAL-RELIGIOUSITY-INDEX.pdf?tid=lk_inline_manual_27, last accessed January 3, 2020.

Ibid.

Shmuel N. Eisenstadt, Multiple Modernities 129 Daedalus 1-29, at 17 (2000).

23 See the chapters by Ratna Kapur, Charles Manga Fombad, Abdullahi Ahmed An-Na'im, Roshan de Silva-Wijeyeratne and Ronojoy Sen in this volume.

24 See Francesco Biagi's chapter in this volume.
} 
Globalization and mass-scale migration have produced a blurring of the line between the private sphere and the public sphere. Mass migration has transformed Western countries from highly homogeneous societies into multicultural, multi-religious polities, triggering defensive reactions and testing the limits of constitutional secularism in ensuring religious toleration. Against the "assumption that tolerance would inevitably arise in secular systems based on reason," ${ }^{25}$ in Western democracies religious freedom has turned into a highly controversial right - as testified by the rise in fundamental rights litigation involving religious arguments, such as in conflicts involving religious symbols in the public sphere ${ }^{26}$ and the construction of worship places for minority religions.

The repoliticization of religion poses a formidable challenge to the essential tenets of the Enlightenment project, upon which Western constitutionalism is grounded. Western constitutionalism presupposes a neat separation between the realm of faith and that of reason, and is committed to ruling the public sphere according to the dictates of reason. ${ }^{27}$ Accordingly, while religion might be the ultimate inspiration of political action, arguments admitted in the political arena must derive exclusively from public reason. ${ }^{28}$ In The Idea of Public Reason Revisited, the liberal political theorist John Rawls argued that religious doctrines should endorse constitutional democracy, which is the only fair way to ensure that the liberty of their adherents is consistent with the equal liberties of other reasonable, free and equal citizens. Importantly, Rawlsian public reason requires a religiously pluralistic polity, where all citizens, irrespective of their faith, feel a "duty of civility." For religious citizens, this means that they should use arguments and ideas that, albeit rooted in religion, are in harmony with toleration for all and with fundamental rights. ${ }^{29}$

Our current predicament does not satisfy these conditions..$^{30}$ As to the first of these, in spite of the existence of a religiously pluralistic polity and the changes brought by mass-scale migration, Western countries remain predominantly Christian. Religious pluralism thus amounts to the juxtaposition of a religious majority (often highly secularized) and various religious and non-religious minorities. While Western constitutions grant all citizens equal religious rights, power relations among religious groups are strongly unbalanced, and the public sphere and the political arena are de facto not equally accessible to individuals within the majority and to those belonging to minority groups. Moreover, as indicated in Section 1, all Western models for managing the relationship between the state and religion share a common feature: a degree of entanglement between national identity and the polity's Christian heritage. Secularization implied a process of separation between the state and Christian churches,

\footnotetext{
25 Marilyn Booth, Review of Talal Asad, Formations of the Secular: Christianity, Islam, Modernity, 4 Bryn Mawr Review of Comparative Literature 2 (2004).

26 Susanna Mancini, The Power of Symbols and Symbols as Power: Secularism and Religion as Guarantors of Cultural Convergence, 30 CARDOZO LAW REVIEW 2639-68 (2009).

27 The following discussion draws on Susanna Mancini, Global Religion in a Post-Westphalia World, in Handbook on Global Constitutionalism 421-32 (Anthony F. Lang and Antje Wiener eds., 2018).

28 John Rawls, Political Liberalism (1993).

29 John Rawls, The Idea of Public Reason Revisited, 64 UNIVERSITY of CHICAGO LAW REVIEW 765-807 (1997).

30 The following discussion draws on Susanna Mancini, Strong Religion and Week Minorities: A Cautionary Tale from Europe, in Key Developments in Constitutionalism and Constitutional LAW 33-47 (Lidija R. Basta Fleiner and Tanasije Marinković eds., 2014).
} 
and hence it naturally entailed the accommodation of the majority's (Christian) religion. Religious tolerance thus was bent on keeping religious diversity within the private sphere; while the public sphere was imbued in cultural Christianity - as vividly exemplified in the 1789 speech by Clermont-Tonnerre regarding the enfranchisement of the Jews during the French Revolution: "We must refuse everything to the Jews as a nation and accord everything to the Jews as individuals." 31 Today, however, this traditional model of tolerance for religious minorities in predominantly Christian countries - characterized by a strict separation between "private" and "public" - fails to meet the needs of less homogeneous polities, where the private and public spheres collapse into one another, and religious diversity can no longer be confined to the private sphere. Indeed, in such contexts, deprivatized religion is detrimental to religious freedom and religious and cultural pluralism, as it tends to strengthen the privileges of majority denominations and relegate religious and non-religious minorities to the democratic periphery. A case decided in the United Kingdom provides a particularly telling example of such perils. ${ }^{32}$ In 2009, the U.K. Supreme Court held a state-funded Jewish school to be guilty of discrimination based on ethnic origin due to the way it operated its admissions policies. ${ }^{33}$ The school applied the traditional religious matrilineal rule, according to which to be Jewish, one must be born of a Jewish mother or to a woman who converted to Judaism prior to the child's birth. The Supreme Court held that the school breached Section 1 of the Race Relations Act $1976^{34}$ because its admission criteria were based on applicants' ancestral origins, and not on their subjective perception as Jews and their practicing of the Jewish religion. Therefore, the admission test was not considered to be religious in nature, but rather ethnic based. The Supreme Court instructed the school to establish a new test that did made determinations of Jewish identity based not on ethnicity, but on religious practice. The ultimate irony is that this test projects onto Jews the Christian, voluntaristic understanding of religious membership, by establishing that a Jew is someone who participates in the observance of the Jewish religion. This case dealt with the claim of a non-Christian denomination to be placed on an equal footing with Christianity in the field of education - that is, within the public sphere. In England, a significant number of state-funded schools are faith-based schools. The overwhelming majority of them are Christian (Church of England and Catholic); only a tiny minority - less than 1 percent - of the maintained faith-based schools are not associated with the major Christian denominations. ${ }^{35}$ In this light, the Jewish school case seems to suggest that,

31 Stanislas-Marie-Adélaide De Clermont-Tonnerre, Speech on Religious Minorities and Questionable Professions, first published 1789, in The French Revolution and Human Rights: A Brief Documentary History (Lynn Hunt ed., 1996).

32 See for a critical reading of this case, Susanna Mancini, To Be or Not to Be Jewish: The UK Supreme Court Answers the Question, 6 European Constitutional Law Review 481-502 (2010).

33 R. v. The Governing Body of JFS, UKSC (2009) No. 15.

34 Section 1 Race Relation Act 1976: "(1) A person discriminates against another in any circumstances relevant for the purposes of any provision of this Act if- (a) On racial grounds he treats the other less favourably than he treats or would treat other persons [...]."

35 In January 2019, there were 6802 state-funded faith schools in England (around 34 percent of all state-funded mainstream schools). Church of England schools were the most common type among primary schools ( 26 percent of all primaries); Roman Catholic schools the most common at secondary level ( 9 percent). Non-Christian faith schools remained very much in the minority: when combined, they made up less than 1 percent of all state-funded mainstream schools. See Faith Schools in England, House of Commons Library, Briefing Paper Number 06972, December 20, 2019, p. 17. 
to be equal in the public sphere, minorities are required to adapt to the mainstream religious culture by incorporating Christian attributes.

The second condition put forward by Johns Rawls - that is, the "duty of civility" of religious and non-religious citizens - also proves problematic. The politicization of religion has produced a blurring of the line between faith and reason: religious arguments - often cast in the language of "natural law" - are increasingly invoked by political actors to antagonize the "culture of rights" and the very legitimacy of the dominant conception of constitutionalism and its nexus to the principle of secularism. An example of this tendency is provided by the launch, in 2019, by U.S. Secretary of State Mike Pompeo, of a "Commission on Unalienable Rights," to introduce "reforms of human rights discourse where it has departed from our nation's founding principles of natural law and natural rights." ${ }^{\prime 6}$ The Commission is chaired by Harvard Professor Mary Ann Glendon, according to whom:

the post-World War II dream of universal human rights risks dissolving into scattered rights of personal autonomy $[\ldots]$ a range of novel sexual liberties might one day become the bread and circuses of modern despots - consolation prizes for the loss of effective political and civil liberties. ${ }^{37}$

Pompeo himself decried the merger between "unalienable," or God-given, and man-made (ad hoc) rights - a dichotomy that contradicts the fundamental tenet of human rights law that all rights are universal and equal, interdependent and interrelated. ${ }^{38}$

Reliance on "natural law" and "natural rights" goes hand in hand with the elevation of religious freedom as a fundamentally unconstrained right. The Archbishop of Canterbury provided a vivid example of this conceptualization in a lecture delivered in 2008, when he decried:

the reluctance of a dominant rights-based philosophy to acknowledge the liberty of conscientious opting-out from collaboration in procedures or practices that are in tension with the demands of particular religious groups: the assumption, in rather misleading shorthand, that if a right or liberty is granted there is a corresponding duty upon every individual to "activate" this whenever called upon. ${ }^{39}$

In this light, freedom of religion should include freedom of conscience - understood as an absolute right not to comply with general laws and policies that go against traditional Christian morality in the fields of sexual and reproductive rights. ${ }^{40}$ In the past years, countless cases have been litigated on both sides of the Atlantic concerning refusals to provide services to women

36 National Archives, Federal Register, A Notice by the State Department on 05/30/2019: Department of State Commission on Unalienable Rights, www.federalregister.gov/documents/2019/05/30/2019 -11300/department-of-state-commission-on-unalienable-rights, last accessed January 3, 2020.

37 Mary Anne Glendon, Reclaiming Human Rights, First Things (August 2016), www.firstthings .com/article/2016/08/reclaim-human-rights, last accessed January 3, 2020.

38 "All human rights are universal, indivisible and interdependent and interrelated. The international community must treat human rights globally in a fair and equal manner, on the same footing, and with the same emphasis." Art. 5, Vienna Declaration and Programme of Action (adopted by the World Conference on Human Rights in Vienna on 25 June 1993), www.ohchr.org/EN/ProfessionalInterest/ Pages/Vienna.aspx, last accessed January 3, 2020.

39 Rowan Williams (Archbishop of Canterbury), Civil and Religious Law in England: A Religious Perspective - Temple Festival series at the Royal Courts of Justice, February 7, 2008.

40 Susanna Mancini and Michel Rosenfeld, Introduction. The New Generation of Conscience Objections in Legal, Political, and Cultural Context, in The Conscience Wars. Rethinking the 
and sexual minorities based on religious objections. ${ }^{41}$ These include mass objection by medical personnel to performing abortions $;{ }^{42}$ public servants refusing to register same-sex unions and therapists refusing to counsel gay clients, ${ }^{43}$ business owners refusing to provide insurance coverage for contraception for their employees, ${ }^{44}$ pharmacies turning away women seeking to buy emergency contraception, ${ }^{45}$ photo studios and bakers refusing to provide their services for same-sex weddings ${ }^{46}$ hospital personnel objecting to carrying on administrative tasks ${ }^{47}$ and hotels owners refusing to accommodate same-sex couples. ${ }^{48}$ Divisions within the dominant cultural and religious traditions figure prominently in the intensification of the "conscience wars" as a consequence of the widening divide between the revival already alluded to of strong religion and its repoliticization on one hand; and the expansion of secular liberalism's fundamental rights to previously broadly excluded or discriminated-against segments of the polity - such as women and lesbian, gay, bisexual, transgender and queer (LGBTQ) persons - on the other.

\section{RELIGIOUS NATIONALISM AND RELIGIOUS POPULISM}

The repoliticization of religion has tended to embrace two separate but often overlapping forms. The first of these is religious nationalism, which essentially consists of "the fusion of religious and national identities and goals." ${ }^{49}$ The second is religious populism, whereby "traditional religion serves to legitimize a social order, a particular regime, or a political community against" what it casts as "destructive forces."

Balance Between Religion, Identity and Equality 1-20 (Susanna Mancini and Michel Rosenfeld eds., 2018).

${ }_{41}$ See the chapter by Isabelle Rorive and Ana Maria Correa in this volume.

42 See, for example, the decision against Italy by the European Committee on Social Rights in International Planned Parenthood Federation European Network (IPPF-EN) v. Italy, Complaint no. 87/2012 (ECSR, decision adopted on September 10, 2013 and delivered on March 10, 2014).

43 See, for example, the Ladele and McFarlane decisions of the European Court of Human Rights in the joint cases of Eweida and Others v. The United Kingdom, Applications no. 48420/10, 59842/10, 51 671/10 and 36516/10 (January 15, 2013) and the decision in April Miller et al. v. Kim Davis, 15-5961 (Appellate Div., 6th Cir., 2015).

${ }_{44}$ See, for example, the US Supreme Court decision in Burwell v. Hobby Lobby, 573 U.S. (2014).

45 See, for example, the decision of the Spanish Constitutional Tribunal in S.T.C., July 7, 2015 (S.T.C., No. 52) (Spain).

46 See, for example, the decision of the U.S. Supreme Court in Masterpiece Cakeshop v. Colorado Civil Rights Commission, 584 U.S. (2018).

47 See, for example, the decision of the U.K. Supreme Court in Greater Glasgow Health Board (Appellant) v. Doogan and Another (Respondents) (Scotland) [2014] [2015] AC640, [2015] 2 All ER 1, [2015] 1 AC 640, [2014] UKSC 68.

48 See, for example, the decision of the U.K. Supreme Court in Bull and another (Appellants) $v$ Hall and another (Respondents) [2013] UKSC 73.

49 Anna Grzymala-Busse, Religious Nationalism and Religious Influence, in OXFORD ReseARCH Encyclopaedia, Politics 1 (2020) (online publication 2019), https://oxfordre.com/politics/view/ 10.1093/acrefore/9780190228637.001.0001/acrefore-9780190228637-e-813, last accessed January 20, 2020.

50 Jose Pedro Zúquete, Populism and Religion, in The Oxford Handbook of Populism 446 (Cristóbal Rovira Kaltwasser, Paul Taggart, Paulina Ochoa Espejo, and Pierre Ostiguy eds., 2017). 
Since the Enlightenment, nationalism has been mainly correlated with secularism. Sociologists conceptualize nationalism as the product of the decline of religiosity among European intellectuals during the nineteenth century - a "surrogate theodicy," which came to replace religion as the main binding force within a political community. ${ }^{51}$ As Ernst Gellner observed, nationalism became the expression of "a political principle which holds that the political and national unity should be congruent." ${ }^{25}$ In our current predicament, however, religion has regained a crucial role in defining political identity. In canvassing through contemporary political identity, one is bound to encounter instances of religious nationalism, instances of religious populism and cases where the two join forces.

Israel is a prime example of a religious nationalist state. Because Judaism is the religion of a given people, there is some fudging between the religion itself and the culture that defines "Jewish peoplehood." In 2018, the Knesset adopted a highly controversial Basic Law entitled: "Israel - the Nation State of the Jewish People." The Law stipulates, inter alia, that the land of Israel is the historical homeland of the Jewish people; that the state of Israel is the nation state of the Jewish people, in which it realizes its natural, cultural, religious and historical right to self-determination; and that exercising the right to national self-determination in the state of Israel is unique to the Jewish people ${ }^{53}$ - in spite of the fact that 20 percent of the country's citizenry is Arab. ${ }^{54}$

Religious nationalism has also reclaimed a fundamental role in the former Soviet Union, where it has filled the void left by the demise of official communist doctrine. Indeed, in Russia, the Russian Orthodox Church (ROC) has become the elite's most important ally in the promotion of "traditional values," as the primary source of national identity; as an avenue to the country's autonomous path of modernization; and as a way to assert Russia's prominence in the new world's order. ${ }^{55}$

In another telling case, the Turkish Justice and Development Party (AKP) led by Recep Tayyp Erdogan launched a neo-conservative Muslim political doctrine, as an alternative modernization project. ${ }^{56}$ Central to this is the use of religion to (re)define Turkish national identity, by recreating Turkish society through a romanticized version of the Ottoman past, as intertwined with Islam. In a reversal of Edward Said's Orientalism, Islamic civilization is pitted against the secular West, and Islam is enlisted to consolidate the bounds of Turkish identity. ${ }^{57}$ As a consequence, the education system, judiciary, police and military schools have undergone a deep Islamization process, ${ }^{58}$ and Islam has become a "re-born element of the new Turkey and

\footnotetext{
51 See Anthony Smith, The Ethnic Revival in the Modern World (1981).

52 ERnst Gellner, Nations and Nationalism (1st edition) 1 (1983).

53 Basic Law Israel - the Nation State of the Jewish People passed on July 19, 2018, https://knesset .gov.il/laws/special/eng/BasicLawNationState.pdf, last accessed January 20, 2020.

54 See the chapter by Gila Stopler in this volume.

55 See the chapter by Kristina Stoeckl in this volume. See also Alicia Curanović, The Guardians of Traditional Values. Russia and the Russian Orthodox Church in the Quest for Status, 1 Transatlantic Academy Paper Series 3 (20142-15).

56 Alev Cinar, Modernity, Islam, and Secularism in Turkey: Bodies, Places, and Time (2005).

57 M. Hakan Yavuz, Erdogan's Ottomania, Boston Review (August 8, 2018), http://bostonreview .net/politics/m-hakan-yavuz-erdogan-ottomanophilia, last accessed January 20, 2020.

${ }_{58}$ M. Hakan Yavuz and Ahmet Erdi Öztürk, Turkish Secularism and Islam Under the Reign of Erdoğan, 19 Southeast European and Black Sea Studies 1-9 (2019).
} 
has been transforming many areas such as: the media, the Kurdish issue, implementation of the rule of law, foreign policy and gender issues." 59

For its part, Hungary - by combining its 2012 Constitution with the leadership of Viktor Orban - provides an example of a versatile use of the rhetoric of religious nationalism which applies both to the country itself and to Europe as a political unit. The Hungarian Constitution's Preamble "recognises the role of Christianity in preserving nationhood." However, it also refers to the role of King Saint Stephen in making the country "a part of Christian Europe," projecting the ethos of religious nationalism at the scale of both Hungary and Europe, as political units that are framed as Christian imagined communities. ${ }^{60} \mathrm{In}$ his political programme to systematically prevent Muslim immigration (contrary to the country's obligation under EU law), Orban heavily draws on the rhetoric of Christian nationalism. In 2015, he wrote in a German newspaper:

Those arriving have been raised in another religion, and represent a radically different culture. Most of them are not Christians, but Muslims. This is an important question, because Europe and European identity is rooted in Christianity. Is it not worrying in itself that European Christianity is now barely able to keep Europe Christian? There is no alternative, and we have no option but to defend our borders. ${ }^{61}$

In the United States, an initially secular right-wing movement (the Tea Party) has been stirred toward religious populism through a partnership with Evangelical fundamentalists. What is at play here is a convergence between a free market ideology that mistrusts all but minimal government, and a Protestant interpretation of biblical sources. The resulting populism consists in emphasizing a perceived threat against America by the liberal "godless" political and cultural elites. ${ }^{62}$

In both Western Europe and North America, contemporary paroxysm around Muslim citizens and migrants goes hand in hand with a renewed emphasis not only on the Christian, but also on the secular roots of Western civilization. Indeed, Islamophobia seems capable of gluing together apparently irreconcilable components of European democracies: from openly racist populist parties - such as the French Rassemblement National - to secular defenders of women's rights; and from Christian conservative circles to mainstream political actors. Anti-Muslim discourses are united by a common accusation: that of adhering to a religious value-system incompatible with Western democracy. On the one hand, political belonging is increasingly understood in terms of a distinction between the Western secular self and a religiously threatening Muslim other. At the same time, cultural Christianity has regained an overriding influence in constituting the imagined identity of Western peoples. One can think of many examples, including the French, Belgian and Quebecois bans on Muslim women's traditional attires on the ground of laicité, ${ }^{63}$ on the one hand; and the decision of the U.S.

\footnotetext{
$59 \quad$ Id.

60 Benedict Anderson, Imagined Communities: Reflections on the Origin and Spread of Nationalism (2006).

${ }^{61}$ Robert Mackey, "Hungarian Leader Rebuked for Saying Muslim Migrants Must be Blocked to 'Keep Europe Christian"” The New York TIMES, September 2, 2015, www.nytimes.com/2015/09/04/ world/europe/hungarian-leader-rebuked-for-saying-muslim-migrants-must-be-blocked-to-keep-europe -christian.html, last accessed April 272017.

62 Zúquete, supra note 50, at 448.

63 See the chapters by Ratna Kapur and by Susanna Mancini and Elena Cohen in this volume.
} 
Supreme Court in Town of Greece, on the other hand. In the latter case, the court found that the delivery of a Christian prayer at the opening of the town board meeting does not violate the First Amendment prohibition of an establishment of religion, because "legislative prayer has become part of our heritage and tradition, part of our expressive idiom." ${ }^{94}$ A similar dynamic is at play in India, where the Hindu right - a conservative religious political movement whose objective is to transform India into a Hindu state - seeks to weaponize secularism by promoting it as compatible with Hinduism and contrary to Islam. ${ }^{65}$

The interplay of secularism and religion has thus become a central feature of contemporary struggles over identity and citizenship. This dynamic ultimately blurs the line between secularism and religion: the first loses its historical and ideological component, and the latter ceases to be a belief system. Secularism and religion become empty, and yet powerful representations of romanticized identities that mark clear-cut divisions between insiders and outsiders.

\section{THE GLOBALIZATION OF RELIGION}

Since the inception of the new millennium, religion has regained center stage internationally. Many factors have contributed to the internationalization of political religious activism, including the ideological void produced by the end of the East-West divide; the erosion of state sovereignty; the proliferation of diaspora religious cultures; and the spread of new media of communication. Pentecostal and Charismatic groups have spread dramatically worldwide, especially in the Global South; and so have transnational Islamic networks. ${ }^{66}$ On the one hand, globalization and mass-scale migrations have facilitated the detachment of religion, culture and territory, setting the premise for a fundamentalist turn of religion, because its claim of a universal truth is inherently disconnected from particular states and societies. ${ }^{67}$ Today, for example, one-third of the world's Muslims live in non-predominantly Muslim states. Radicalization mostly occurs among the second and third-generation migrants in Western countries, who strive to establish an imagined Islamic community (an ummah), uprooted from any particular state or society. This, as remarked by sociologist Olivier Roy, has resulted in the building of a universal religious identity that transcends the very notion of culture. ${ }^{68} \mathrm{On}$ the other hand, new communication technologies help keep alive the ties among members of dispersed religious communities, irrespective of political and geographical boundaries. As Mark Juergensmeyer has observed:

Many of the online supporters of ISIS are tied not only by religious affiliations but also by ethnic ones, since many are part of Algerian, Libyan, and other diasporic communities. Expatriates such as Irish Republicans, Indian Sikhs, and both Sinhalese and Tamil Sri Lankans have provided both funding and moral support to their compatriots' causes. ${ }^{69}$

Town of Greece v. Galloway, 572 U.S. 565 (2014).

See the chapters by Ratna Kapur, and by Ronojoy Sen and Farrah Ahmed in this volume.

Jonathan James, Transnational Religious Movements: Faith's Flows (2017).

Olivier Roy, Holy Ignorance: When Religion and Culture Part Ways (2010).

Olivier Roy, Globalized Islam. The Search for a New Ummah (2004).

9 Mark Juergensmeyer, Religious Nationalism in a Global World, 10 ReLIGIONs 97 (2019). 
Interestingly, the success of transnational religions is not limited to movements such as Pentecostalism, which do not rely either on a highly centralized structure or on historical links to tradition while having no territorial roots or identity. To the contrary, globalization has set the terrain for Catholicism to recuperate its transnational dimensions "which had been characteristic of medieval Christendom, from the transnational Papacy to transnational religious orders, to ecumenical councils, to transnational universities and centers of Catholic learning, to transnational pilgrimages," and which had disappeared with the emergence of the Westphalian system..$^{70}$

The repoliticization of religion has profoundly shaken the foundations of the Westphalian model of coordination of religion and political boundaries. ${ }^{71}$ The Peace of Westphalia, which brought about the end to the Thirty Years' War, established the principle according to which each sovereign would have the right to determine the religion of his own state (cuius regio eius et religio). To achieve this aim, "territorial arrangements were adjusted to accommodate religions and minimize immigration." 72 Moreover, Westphalia obliged states to confer fundamental religious freedoms to non-established Christian minorities, thus establishing a principle of religious toleration. ${ }^{73}$

This produced two crucial consequences: in the first place, it enabled states to regulate religion as part of state sovereignty, which encompassed the power to determine the frontiers of religious jurisdiction. In the second place, Westphalia "secularized international relations by undermining religion as a mode of legitimacy." 74 The sovereign state became the basic unit of international relations, in a system in which each state recognized the others as the final authorities within their given territories. ${ }^{75}$ State rulers thus ceased supporting their co-religionists in their conflicts beyond the borders of their own polity, which greatly limited the Vatican's extraterritorial authority. As Leo Gross famously put it, in this respect Westphalia "was said to be 'a public act of disregard of the international authority of the Papacy."'76

Our current predicament is increasingly characterized by an "undoing" of Westphalia ${ }^{77}$ - that is, by the reappropriation by religions of an international role; by the competition of religious worldviews; by states' claims of extraterritoriality in the field of religion; as well as by religious conflicts and wars of religion.

In 1998, the U.S. Congress adopted the International Religious Freedom Act, which mandates the promotion of religious freedom around the world as a core element of U.S. foreign policy. The Office of International Religious Freedom was established with the task of monitoring religious persecution and discrimination worldwide; recommending and implementing

70 José Casanova, Public Religions Revisited, in Religion: Beyond the Concept 101-19 (Hent de Vries ed., 2008).

71 Mancini, supra note 27, at 421-32.

72 Gordon A. Christenson, Liberty of the Exercise of Religion in the Peace of Westphalia, 21 Transnational Law \& Contemporary Problems 739 (2013).

73 Christenson, supra note 72 , at 740.

74 Benno Teschke, The Myth of 1648: Class, Geopolitics and the Making of Modern International RELATIONS 3 (2003).

75 Derek Croxton, The Peace of Westphalia of 1648 and the Origins of Sovereignty, 21 THE InTERnAtional History ReVIEW 570 (Sep. 1999).

76 Leo Gross, The Peace of Westphalia, 1648-1948, 42 The American Journal of InTERnational LAW 28-29 (1948).

77 Daniel Philpott, Religious Freedom and the Undoing of the Westphalian State, 25 MichIGAN JoURNAL OF INTERNATIONAL LAW 981-98 (2004). 
policies in respective regions or countries; and developing programs to promote religious freedom. The U.S. model was soon replicated by Canada and the European Union. ${ }^{78}$ Exporting American (or Western) religious freedom internationally ${ }^{79}$ inevitably carries the risk of Westernizing religion. Indeed, identifying from a Western perspective which forms of religion are to be protected and which are not risks altering and/or marginalizing religious expressions that do not fit the Western model or do not serve Western interests. ${ }^{80}$ International protection of religious freedom can thus turn into an imperialistic attempt of cultural colonization which risks fueling violence rather than promoting religious peace.

The "export" of religion is by no means a singular Western phenomenon. The Turkish AKP also heavily relies on Islam in its foreign policy. "In countries from Latin America to sub-Saharan Africa, Turkey is building mosques, financing religious education, restoring Ottoman heritage - and advertising its unique brand of Islamic leadership along the way." 81 Conflating Sunni Islam with national identity, Turkish institutions engage in the international promotion of their language and culture alongside religious curricula, portraying Turkey as the "heir to the Ottoman Empire, Islam's last fortress and the natural leader of a revival of Muslim civilization." $" 82$ Similarly, Iran and Saudi Arabia compete worldwide to establish their brand of Islam by funding religious organizations and financing the building of mosques abroad ${ }^{83}$

Religion has also become a crucial element of Russia's foreign policy, where the convergence of interests between the political leadership and the ROC is responsible for shaping the country's international human rights agenda, according to "traditional values." The ROC has designed its human rights agenda "as an 'alternative' human rights discourse, in competition with secular liberal human rights activists." ${ }^{84}$ Domestically, the ROC aims to prevent any liberalizing influence of international human rights on family law. Internationally, the ROC - exhausted by decades of litigation before the European Court of Human Rights (ECtHR) pursues its interests by seeking conservative allies, such as American right-wing Evangelicals, the Vatican and other conservative Christian churches. The Russian leadership, for its part, favors a multipolar international system not bound by international human rights law, in order to avoid international interference in its domestic politics. ${ }^{85}$

These developments have turned the United Nations (UN) into a venue of bitter confrontation among supporters of different conceptions of religious freedom and, more generally, of the role of religion in the international legal order. In 2011, the UN Human Rights Council passed a resolution entitled "Promoting human rights and fundamental freedoms through

\footnotetext{
78 Pasquale Annicchino, Law \& International Religious Freedom. The Rise and Decline of THE AMERICAN Model (2017).

79 For a historical analysis of the US engagement in the international protection of religious freedom see Anna Su, Exporting Freedom: Religious Liberty and American Power (2016).

80 Elizabeth Shackman-Hurd, Beyond Religious Freedom: The New Global Politics of RELIGION (2015).

81 Gonul Tol, Turkey's Bid for Religious Leadership How the AKP Uses Islamic Soft Power, ForeIGN AfFAIRS (January 2019), www.foreignaffairs.com/articles/turkey/2019-01-10/turkeys-bid -religious-leadership, last accessed January 20, 2020.

82 Tol, supra note 81.

83 Tol, supra note 81.

84 Kristina Stoeckl, The Russian Orthodox Church and Human Rights 50 and 95 (2014).

85 StOECKL, supra note 84, at 113.
} 
a better understanding of traditional values of humankind." ${ }^{\prime 66}$ The resolution - which echoes the position of the ROC concerning the foundations and scope of human rights - was prompted by the Russian government, which gained the support of the Global South, including countries of the Arab league. The European Union pointed to the "potential harm posed by the concept of traditional values in undermining the universality and inalienability of human rights." 87 Hence the resolution can be viewed as part of an attempt by Russia to reaffirm the transcendent foundations of human rights and the role of religion in shaping the international human rights regime as a strategy to impose an ideological monopoly. This is achieved by bringing together conservative governments and religious actors from different Christian denominations, unified by an agenda mostly focused on opposing LGBTQ rights and women's equality. ${ }^{88}$

Transnational religious actors actively engage in both domestic and international litigation. ${ }^{89}$ Numerous nongovernmental organizations (NGOs) and pro-bono legal organizations specialize in high-impact litigation before national, regional and international judicial bodies, such as the ECtHR, in cases regarding "sensitive" issues such as gay marriage, abortion, conscientious objection and religious freedom. Many of these lobbies are based in the United States, and have offices or branches in Europe and elsewhere, where they cooperate with local partners through training, funding and legal advocacy. The conservative Christian Alliance Defending Freedom, for example, defends "religious freedom, the sanctity of life, and marriage and family around the world," on the ground that "international cases have the potential to set legal precedents that cross national borders and even impact US law." $" 90$

A powerful network of faith-based NGOs - mainly led by US Evangelicals and other right-wing Christians - has also become highly influential in constitution making and in shaping legislation abroad. In Africa, organizations such as the American Center for Law \& Justice, Human Life International and Family Watch International have been progressively colonizing African values by "expanding colonial-era proscriptions" on sexual rights. The success of such organizations is due to their capacity to "espouse charismatic and other conservative theologies [that] resonate with many African Christians," while simultaneously "painting African campaigners for LGBT rights as dupes of neo-colonial forces trying to impose an alien philosophy on the continent." 91

86 Resolution A/HRS/16/L.6 entitled "Promoting human rights and fundamental freedoms through a better understanding of traditional values of humankind", March 24, 2011.

87 EU Statement to the Human Rights Council, September 13, 2013.

88 See UN High Commissioner for Human Rights, Summary of information from States Members of the United Nations and other relevant stakeholders on best practices in the application of traditional values while promoting and protecting human rights and upholding human dignity, A/HRC/24/22, para 3 , cautioning against the negative impact on the implementation of human rights, "especially those concerning violence against women, sexual orientation, gender identity, age and disability."

89 See Christopher McCrudden, Transnational Culture Wars, 13 International Journal of Constitutional Law 434-62 (2015).

90 Alliance Defending Freedom, www.adflegal.org/issues/international/overview, last accessed 3 May 2020.

91 Kapia John Kaoma, Colonizing African Values: How the U.S. Christian Right is Transforming Sexual Politics in Africa VI (2012), www.sxpolitics.org/wpcontent/uploads/2012/08/ colonizingafricanvaluespra.pdf, last accessed January 20, 2020. 


\section{ORGANIZATION OF THE HANDBOOK}

The various chapters of this handbook collectively analyze and address the essence of the issues laid down in the previous pages. They do so mainly through the lenses of comparative constitutional law. Indeed, in recent years, studies by comparative constitutional law scholars have played an important role in the global debate concerning the legal treatment of religion in the public sphere. The "place" of religion in the constitutional order is a crucial indicator of the nature of the constitution, which greatly contributes to shaping the relationship between national and constitutional identity. What forms of church-state relations and how much - if any - religious freedom is required in a constitutional system are markers of the liberal/illiberal nature of the system; of the fundamental values it adheres to; and of the aspirations of a state in the international community. Moreover, the epistemological perspective taken by comparative constitutional lawyers often differs from the traditional approach of law and religion scholars, in that it places religious issues within a broader perspective - one that assesses the impact of a state's structures on the enjoyment of religious freedoms. Factors such as the horizontal separation of powers, the control mechanism of checks and balances, the model of constitutional adjudication and issues of federalism and devolution profoundly affect the protection of fundamental rights, and thus of religious freedom. Furthermore, at a time when international human rights regimes are increasingly contested, the comparative constitutional law discipline provides for critical analysis of the limits of universalism, local relevance and applications.

This being said, no single discipline may alone do justice to the complexities and the nuances that are raised by the treatment of religion in a constitutional setting. Thus, the authors of this Handbook also provide their insights from legal and political theory, sociology and political science. Across all of their contributions, however, there is a recognition that in the contemporary context, neither constitutionalism nor religion can be fully grasped without a focus on their inescapable connections.

Part I of the Handbook tackles philosophical and historical issues. It explores the history of state/church relations and the meaning of concepts such as religious toleration, secularism and religious liberty, in different times and contexts. Part II offers an account of the different constitutional models of managing state/religion relations. Countries are grouped according to functional and regional criteria. This seems preferable to linking countries according to particular characteristics (e.g. the level of entanglement between religion and the state), for two reasons. The first is that the constitutional treatment of religion crystallizes a relationship between distinct entities: the state and one or more religious denomination(s). Hence, the presence of a common religious tradition constitutes a major advantage for any survey of the relations between religion and the state. The second is that the development of regional systems protecting human rights (e.g. the European Union, the ECtHR and the Inter-American Commission on Human Rights) has contributed to the shaping of common grounds among state parties in the protection of religious freedom. Part III addresses how religion affects constitution making and the political party system. Part IV tackles the supranational dimension of religion and religious freedom. It focuses on the conceptualization of religious freedom and of state/church relations in supranational law, as well as on the role of religion in international relations, and the circulation of constitutional arguments that results from judicial lobbying by transnational religious actors. Finally, Part V highlights some of the new, intensified or continuous issues of great interest in the era of the deprivatization of religion, including the 
relationship between gender and religious freedom, conscientious objection, the integration of Islam in Western constitutional settings and the regulation of blasphemy.

The contributions to Part I, which focuses on history and philosophy, start with Michel Rosenfeld's chapter. Rosenfeld offers a Western account of the theoretical and historical development of constitutional secularism and of the principal constitutional models to regulate the church/state relations, from the militant secular model to the model that features an official state religion while commanding tolerance of other denominations. In Chapter 3, Ratna Kapur examines the contradictions and complexities present in the notion of secularism, by comparing its applications in postcolonial India and the French Republic. In particular, she focuses on the implications of the Western and non-Western models of secularism relating to the understanding of citizenship. In contrast, in Chapter 4, Andrew March explores a distinctly non-secular constitutional tradition, by tackling the developments in modern Islamic constitutional theory, with a particular focus on the late twentieth century, when a distinct approach to questions of sovereignty, legal supremacy, judicial review and legislative authority was developed. Finally, in Chapter 5, Peter Danchin - in analyzing a series of recent constitutional and international human rights cases concerning religious freedom - underscores the paradoxes and antinomies internal to the relationship between political secularism and universal rights. These have far-reaching implications for our understanding of religious freedom as a fundamental right subject to the political rationality of the modern state.

Part II, on different models for managing the relationship between religion and the state in various regions of the world and under different legal and religious cultures, starts with Chapter 6 by Silvio Ferrari. Ferrari describes the main historical steps that marked the formation of the idea and of the right of religious freedom in Europe, and highlights the peculiarities and the internal variations of the European model. Chapter 7, by Dia Dabby and Jean-François Gaudreault-DesBiens, zeroes in constitutionalism and religion in two common law countries, Canada and the United States. The authors suggest that transversal frameworks permeate both countries and underline particular axes of convergence and divergence between the two in order to underscore the interplay of constitutionalism and religion in such matters as religious prayers in public institutions, marriage and end-of-life decisions. Julieta Lemaitre Ripoll offers in Chapter 8 an account of the key historical developments in yet another predominantly Christian region: Latin America. She demonstrates how religious freedom was initially asserted by secular liberals against the confessional nineteenth century constitutions. Since the 1990s, however, religious freedom has found a new champion in the Catholic Church, eager to find constitutional protection against increasingly liberal governments in the region. In Chapter 9, Charles Manga Fombad examines, from a comparative perspective, the manner and extent to which religious rights are now recognized, protected and entrenched in modern African constitutions. Fombad emphasizes the diverse approaches taken on the African continent toward the constitutionalization of religious rights and concludes that the full enjoyment of such rights is hampered in practice by an array of challenges. Chapter 10, by Abdullahi Ahmed An-Na'im, raises the question whether Islam as a religion can be captured by the concepts, approaches, processes and analytic tools of comparative constitutionalism. He places particular emphasis on viewing Islam from the perspective of the post-colonial state. Through a historical account of Islam and the development of Sharia, An-Na'im explains, constitutionalism cannot succeed in Muslim majority countries without adjustments and adaptations. In Chapter 11, Roshan de Silva-Wijeyeratne delineates Buddhist constitutionalism, which originates with the birth of the Buddha in his particular political context. He focuses 
specifically on the colonial and post-colonial aftermath of this tradition, which he reinterprets as a means of tackling evolving political conditions as opposed to the original essentialist understanding. Gila Stopler offers in Chapter 12 a critical analysis of the relationship between constitutionalism and religion in Israel as a Jewish and democratic state. Although Israel is generally considered a Western liberal democracy, in terms of religion-state relations it exhibits a semi-liberal constitutionalism, which shares commitments to liberal universalist values and to Orthodox Jewish religious values. This poses difficult challenges for human rights, and especially for women's equality and the proper scope of religious freedom. Chapter 13, by Ronojoy Sen, engages with the complexities of the Indian Constitution's position vis-a-vis Hinduism by looking at three aspects: the reasoning behind the relationship between state and religion as it emerged in India's Constituent Assembly; the judicial interpretation on the freedom of religion clauses with regard to Hinduism; and the right of religious sects or denominations to exit Hinduism. In Chapter 14, Kristina Stoeckl analyzes the current post-Soviet model of managing the relationship between religion and the state in Russia, which she defines as a deficient model of selective cooperation. Indeed, in Russia, three inconsistent models of the relationship in question are at play: that which promotes the ROC as a partner of the state and representative of a majority; a cooperation model, in which the ROC presents itself as a minority in need of protection; and a disestablishment model, in which the ROC acts like a "culture war" antagonist against the state.

In Part III, Francesco Biagi and Luca Ozzano address two crucial aspects of the role of religion in shaping, respectively, the making of the constitution and the state's political party system. Biagi, in Chapter 15, provides an overview of the actors that contribute to shaping the content of constitutional provisions concerning religion and the factors that influence the issue of religion in constitution-drafting processes. He focuses on comparative post-Second World War constitutions and discusses the most contentious issues relating to religion that emerge during debates within constituent bodies. Ozzano, in Chapter 16, draws on examples from different regions and cultural contexts to provide a typology that underscores five models of "religiously oriented" parties, marked by different ideologies, organizational models, social bases, interactions with interest groups and goals.

In Part IV, religious freedom is analyzed in the context of supranational constitutionalism. In Chapter 17 András Sajó and Renáta Uitz focus on freedom of religion under the European Convention of Human Rights. According to them, the ECtHR has displayed a rather generous acceptance of the subject of permissible limitations of religious liberty. Moreover, the ECtHR tends to be less demanding in its use of the standard of proportionality when considering religious liberty rights as opposed to other Convention rights. Chapter 18 by Ronan McCrea shows how issues that arise in the relationship between religion and the constitutional order in liberal democracies generally also arise in a distinctive form within the constitutional order of the European Union. The Union seeks to strike a balance between its need to protect its own distinctive constitutional values and the need to respect member state autonomy in religious matters. The Union's approach to religion is based on two pillars: a predominantly Christian religious heritage of its member states; and a strong secular and humanist tradition that limits the political and legal influence of religion, and requires some degree of separation between religion and state. Finally, in Chapter 19, Christopher McCrudden focuses on the dramatic increase of human rights litigation regarding religious freedom issues. Three ideological developments are responsible for this: first, developments in human rights doctrine resulting in greater conflicts between religious practices and human rights; second, a fundamentalist turn 
within several religions; and third, the geopolitical significances of ideological tensions related to religion. Religion litigation has also increased because of several institutional factors: the courts have become more available; activism by NGOs has risen; and intra-religious factionalism has fueled further conflicts.

Part V of the Handbook, which tackles some of the most salient challenges and controversies in a world marked by the repoliticization of religion, starts with Chapter 20, by Susanna Mancini and Elena Cohen. The authors revisit the debate launched by Susan Okin in the 1990s on the perils of accommodating minority religions for the pursuance of gender equality. They argue that while these tensions can by and large be navigated by legal systems, notions of secularism and gender equality are often used to assert Western cultural superiority. Most importantly, however, in recent times, the backlash against women's equality has primarily resulted not from the accommodation of religious minorities, but from the weaponization of majority religions within legal systems to reassert traditional gender roles. In Chapter 21, Isabelle Rorive and Ana Maria Corrêa trace the legal narrative of conscientious objection based on religious and other ethically salient grounds. They demonstrate how this rhetoric has evolved from military contexts to a broad range of situations, including public health, public administration and the provision of goods and services; and they assess the impact of these developments on protections under the right of equality. In Chapter 22, Christian Joppke concentrates on the place of Islam in European constitutional law and jurisprudence. He draws attention to the distinction between Islamic parity claims, which call for equal treatment between Muslims and non-Muslims, and for exemptions from those secular rules that conflict with perceived Islamic religious norms. Joppke concludes that while parity claims are incontrovertible, exemption claims are more problematic and thus cannot be fully accommodated. In Chapter 23, based on the example of Ireland, Neville Cox argues that although blasphemy laws objectively limit free speech, when properly handled under the principle of proportionality, they can strike a desirable balance between freedom of expression and public morality. Finally, in Chapter 24, Farrah Ahmed - focusing in particular on the Indian case - examines whether personal law systems that regulate family matters based on religious doctrine contribute successfully to the promotion of religious pluralism. 